\title{
A INTERNACIONALIZAÇÃO DE EMPRESAS BRASILEIRAS DE BENS DE CAPITAL: O CASO DA ROMI E DA WEG
}

\author{
THE INTERNATIONALIZATION OF BRAZILIAN \\ COMPANIES IN THE CAPITAL GOODS INDUSTRY: \\ THE CASE OF ROMI AND WEG
}

\author{
Michel D. Marson \\ Universidade Federal de Alfenas, Brasil, michelmarson@yahoo.com.br \\ Armando João Dalla Costa \\ Universidade Federal do Paraná, Brasil, ajdcosta@uol.com.br
}

\begin{abstract}
Resumo. Apesar do atraso na industrialização de países da América Latina em termos de desenvolvimento tecnológico e investimento em setores industriais mais intensivos em tecnologia do que nos países mais avançados, o acelerado crescimento industrial no Brasil, ao longo do século Xx, criou uma estrutura industrial heterogênea do ponto de vista tecnológico e produtivo, na qual empresas com produção tradicional permaneciam no mercado e complementavam empresas com produção avançada. No artigo lançamos luzes sobre a questão de como o Brasil, com forte crescimento industrial durante o processo de substituição de importações, mas com baixo desenvolvimento tecnológico agregado, gestou empresas que exportaram bens de capital, intensivos em tecnologia, e também se iniciou o processo de internacionalização dessas firmas.
\end{abstract}

Palavras chave: internacionalização; bens de capital; empresas brasileiras; Romi; Weg.

Abstract. Despite the delay in the industrialization of Latin American countries in terms of technological development and investment in more intensive in industrial technology sectors than in rich countries, the quickly industrial growth in Brazil, throughout the 20th century, created a heterogeneous industrial structure point technological and productive sight, in which companies with traditional production remained on the market and complemented with advanced production companies. The purpose of the paper is shed light on how Brazil, with their strong industrial growth during the process of import substitution, but with low added technological development, nurtured companies that exported capital goods, technology-intensive and also initiated the internationalization process of these firms.

Key words: internationalization; capital goods; Brazilian companies; Romi; Weg.

Artigo recebido: 9 de novembro de 2014. Artigo aceito: 19 de janeiro de 2015.

Am. Lat. Hist. Econ., año 22, núm. 3, septiembre-diciembre, 2015, pp. 145-176 


\section{INTRODUÇÃO}

$\mathrm{E}$ m 1990, a Comissão Econômica para a América Latina e o Caribe (CEPAL) identificou que os principais problemas do desenvolvimento econômico da região, pelo processo de substituição de importações, eram o baixo desenvolvimento tecnológico e o crescimento sem equidade. A principal proposta da CEPAL nesse período foi uma transformação produtiva com equidade. Entre 1965 e 1984, nenhum país da região havia atingido o crescimento econômico com igualdade apresentando assim "o conjunto vazio" entre as ralações dessas duas variáveis, ao contrário de países atrasados da Europa e países asiáticos. O traço explicativo do processo de desenvolvimento econômico da América Latina era a incorporação insuficiente de progresso técnico, ou seja, a tecnologia permanecia como uma "caixa preta" para esses países. América Latina no início dos anos 1990 representava $8 \%$ da população mundial, $7 \%$ do produto interno bruto, $6 \%$ da produção industrial, $3 \%$ da produção de bens de capital, $2.4 \%$ dos engenheiros e cientistas e 1\% das publicações científicas do mundo (CEPAL, 2000; Fajnzylber, 2000, pp. 856-857).

Há um debate na literatura sobre a avaliação da industrialização da América Latina após 1930. Para alguns autores o resultado da industrialização foi um desenvolvimento industrial fechado, tecnologicamente atrasado e ineficiente. $\mathrm{O}$ resultado dessa ineficiência no processo de industrialização teria como causa a proteção tarifária, sistema de taxas múltiplas de câmbio, sistema de licenças para importações e participação estatal em empresas e bancos de fomento às indústrias (Haber, 2008, p. 562). Entretanto, para outros autores o resultado do desenvolvimento industrial no Brasil não foi ineficiente no longo prazo. Para Albert Fishlow (2013) a indústria brasileira apresenta uma evolução crescente da produtividade entre 1920 e os anos 1950 em virtude das políticas de substituição de importações, mas esse autor explica que esses ganhos de produtividade foram diferentes na maior parte da América Latina, devido ao menor custo de mão de obra em relação aos países de renda mais alta e ao tamanho do mercado que promoveu economias de escala, aproveitada principalmente pelo capital estrangeiro. Entretanto, para o autor, algumas características desse processo de industrialização foram prejudiciais para o desenvolvimento, tais como: a ênfase da produção liderada pelo consumo com endividamento interno e externo, baixa preocupação com as deficiências educacionais, reduzidas exportações de produtos manufaturados e a pequena produção interna de bens de capital (Fishlow, 2013, pp. 34-35).

Apesar desse aparente atraso em termos de desenvolvimento tecnológico e investimento em setores industriais mais intensivos em tecnologia, o acelerado crescimento industrial no Brasil criou uma estrutura 
industrial heterogênea do ponto de vista tecnológico, na qual empresas com produção tradicional permaneciam no mercado e complementavam empresas com produção tecnologicamente mais avançada. Essa estrutura industrial heterogênea resultou em empresas que tinham como direcionamento de sua produção o mercado interno e empresas que também exportavam, inclusive em setores intensivos em tecnologia, como os bens de capital.

O objetivo do artigo é lançar luzes sobre a questão de como o Brasil, com forte crescimento industrial durante o processo de substituição de importações, no período de 1930-1980, mas com baixo desenvolvimento tecnológico agregado, gestou empresas que exportaram bens de capital, intensivos em tecnologia, e também iniciaram um processo de internacionalização das empresas nesse setor. A próxima seção trata dos conceitos relativos à internacionalização de empresas e foca essa questão para países da América Latina. A seção três apresenta a evolução da indústria de bens de capital no Brasil, uma indústria que tem suas origens no setor de máquinas para agricultura, ainda em um contexto de crescimento econômico direcionado pelas exportações primárias no final do século XIX. Do início, apresentaremos a evolução do setor ao longo do século XX, quando a produção volta-se para máquinas para a indústria e sua mudança estrutural com o desenvolvimento industrial que a torna mais complexa, até a busca por novos mercados e a internacionalização de empresas. A seção quatro tem o objetivo de apresentar estudos de caso dessa internacionalização e a seção cinco faz as considerações finais do trabalho.

\section{A INTERNACIONALIZAÇÃO DE PAÍSES EM DESENVOLVIMENTO: O CASO DA AMÉRICA LATINA}

\section{A internacionalização de empresas}

A internacionalização de empresas não é um fenômeno recente. As multinacionais são resultado do início do próprio capitalismo, na era do mercantilismo, com empresas ligadas ao grande comércio internacional na exploração colonial (Dean, 1983, pp. 9-10). Entretanto, empresas multinacionais modernas iniciaram o processo de produção entre fronteiras de países de forma significativa na década de 1920 (Frieden, 2008, p. 183).

Por exemplo, no Estados Unidos as primeiras firmas multinacionais tiveram origens nos grandes empreendimentos integrados da economia nacional no final do século XIX. Essas empresas criaram uma extensiva organização externa e construíram fábricas no exterior por causa de altas tarifas, alto custo do transporte, baixo custo do trabalho, entre outros fa- 
tores. Em 1914, dois terços das multinacionais norteamericanas operavam nas indústrias de alimentos e de máquinas (Chandler, 1977, pp. 368-369).

O termo "empresa multinacional" apareceu no Estados Unidos nos anos 1960 para caracterizar empresas que possuíam e controlavam capital produtivo em mais de um país. Nesses anos, as multinacionais atingiram representatividade política e social, apesar de terem iniciado a expansão no final do século XIX, resultado da primeira onda de globalização (Valdaliso e López, 2007, p. 371).

A partir dos anos 1870, a origem das empresas multinacionais está relacionada a vários fatores. A mudança na tecnologia da segunda revolução industrial, principalmente nos transportes e na comunicação, resultou na melhora da capacidade de organização da produção, distribuição e gestão. A reação das nações foi o aumento da proteção tarifária. A decisão de instalar fábricas em outros países foi uma reação de superar essas tarifas alfandegárias. Entretanto, houve diferentes motivações entre os setores industriais: para o setor de bens de consumo de marcas a razão para a expansão da produção em outros países foi controlar a qualidade do produto nas filiais; para o setor mineiro, siderúrgico, petroleiro e de borracha, as empresas investiam no exterior para conseguir novos mercados e matérias-primas que não havia em seus países; em setores de serviços, como transporte, comércio, bancos e seguros, o objetivo das empresas multinacionais era facilitar as atividades primárias ou manufatureiras. A forma de investimento externo mudou após a primeira guerra, de criação de novas fábricas para a compra de empresas locais (Valdaliso e López, 2007, pp. 372-374).

J. Dunning (1983) propõe uma explicação eclética para o surgimento das empresas multinacionais. Para ele, deve-se considerar três grandes fatores relacionados: capacidades das empresas, custos de transação e fatores de localização. As capacidades competitivas das empresas multinacionais, em certo mercado, podem ser de tecnologias mais avançadas, estrutura mais eficiente, um conhecimento particular (protegido por patente), capital humano mais qualificado, entre outras. Com relação aos custos de transação, a criação de filiais em outros países pode ser vantajosa se os custos de transação das licenças são elevados ou se as filiais são para obter matéria-prima ou componente a preços mais baratos. A última característica para a expansão das multinacionais levantada por Dunning foi a vantagem e desvantagem da localização, com o tamanho do mercado, a existência de tarifas alfandegárias, entre outros (Valdaliso e López, 2007, p. 372).

O período da depressão dos anos 1930 até a segunda guerra mundial não foi bom para os investimentos no exterior em geral, e particularmente para as empresas multinacionais. A expansão das empresas multinacionais ocorreu a partir dos anos 1950. Três quartos das empresas multinacionais norteamericanas e britânicas, existentes em meados dos anos 1970, foram 
fundadas depois de 1945. A modalidade de expansão exterior desde os anos 1960 foi o investimento direto, explicado pela estabilidade monetária e das relações econômicas. A partir desse período, as empresas multinacionais especializam a produção de suas filiais em áreas determinadas, com ganhos de escala de produção, distribuição e desenvolvimento de produtos específicos. Nos anos 1960 e 1970, as empresas multinacionais focaram sua presença em setores jovens, com tecnologia mais complexa, diminuindo a presença em setores mais tradicionais. Assim, segundo Jones (1996) houve quatro grandes períodos de evolução das empresas multinacionais: crescimento entre 1880 e 1930; crise entre 1930 e 1940; expansão entre 1950 e 1980, e a partir desse ano, a aparição de um mercado global (Valdaliso e López, 2007, pp. 372-376).

\section{A internacionalização de empresas na América Latina}

Apesar do processo de internacionalização de empresas ser um fenômeno clássico de países centrais, em países periféricos ele vem aumentando desde os anos 1990. A participação de empresas de países em desenvolvimento nos investimentos aumentou de $6.3 \%$ entre 1986 e 1991 para $13.8 \%$ em entre 1992 e 1997, sendo a representação da América Latina e Caribe de $1.3 \%$ do investimento direto estrangeiro mundial (Chudnovsky e López, 1999 , p. 2). O processo de internacionalização de empresas da América Latina expandiu nos anos 1990, com as mudanças estruturais nessas economias nesse período. Antes, nos anos 1980, as economias latino-americanas estavam atreladas ao modelo de industrialização por substituição de importações, um modelo de crescimento voltado para dentro. Entretanto no Brasil, entre os anos 1980 e 1990, ocorreu um processo de internacionalização baseada no processo de industrialização por substituição de importações em setores que tinham vantagens de capacidades de desenho ou adaptação de produtos e processos como no ramo de autopeças, metal mecânica, siderurgia e têxtil. A internacionalização de firmas da América Latina foi favorecida pelas transformações econômicas dos anos 1990, com abertura comercial e financeira e reestruturação de suas economias (Chudnovsky e López, 1999, pp. 12, 20).

Nos anos 2000, a expansão de novas multinacionais de países como Brasil, Índia, China, África do Sul e México alteraram o contexto corporativo global. Na América Latina, firmas brasileiras investiram 10000 milhões de dólares fora do país em 2004. Como anteriormente, essa nova onda de internacionalização foi motivada pela pressão competitiva no mercado interno, combinada com estratégias de expansão e diversificação de vendas, mercados e produtos. Poucas empresas latino-americanas tor- 
naram-se líderes globais no mercado em que atuam, as multilatinas, como a Cemex, Vale e Embraer. Muitas das empresas ainda são pequenas em relação às de países centrais, mas estão contribuindo para mudar as fronteiras do empreendimento global, com a expansão de multinacionais de países emergentes (Santiso, 2008).

As atuais multinacionais do Brasil tinham destaque no mercado interno nos anos 1970, com o foco no esforço de exportação. Essas empresas iniciaram novo ciclo no final dos anos 1980 e início dos anos 1990, com as estratégias internacionais para expansão de suas atividades (Cyrino e Barcellos, 2006, p. 227). As maiores empresas brasileiras estão nos estágios iniciais de internacionalização, pois apenas 25\% das 1000 maiores empresas do país realizaram algum investimento internacional, como subsidiárias de comercialização ou produção, sendo a exportação a relação mais próxima com o mercado internacional dessas empresas, mas esse contexto vem mudando nos últimos anos (Cyrino e Oliveira, 2003, p. 15).

\section{A EVOLUÇÃO DA INDÚSTRIA DE BENS DE CAPITAL NO BRASIL}

\section{As origens no século XIX}

É impossível precisar uma data para o surgimento dos primeiros produtores de máquinas e equipamentos no Brasil. Há registros de iniciativas isoladas de reparo de equipamentos no país antes do desenvolvimento da economia primário-exportadora a partir de meados do século XIX. No período colonial a principal demanda por equipamentos derivava do aparelhamento de engenhos de açúcar e derivados da cana. Houve produção de ferramentas e utensílios em fornos rudimentares já no final do século XVI, mas a despeito da facilidade de aquisição de matérias-primas com a descoberta de minério de ferro, o setor não se desenvolveu. Com a independência do país e o advento da economia primário-exportadora a indústria de máquinas e equipamentos iria desenvolver-se na região sudeste do Brasil. Assim, parece ser indiscutível que o ramo industrial e o próprio processo de industrialização do sudeste começaram a se desenvolver com o crescimento econômico impulsionado pela expansão agroexportadora na segunda metade do século XIX.

A historiografia da industrialização brasileira destacou como agentes sociais responsáveis pela gênese da indústria os imigrantes e os fazendeiros ligados à produção de café. Entre os imigrantes existiram diferenças importantes, sendo que parte da historiografia deu destaque para os imigrantes ligados ao comércio de importação, imigrantes de classe média que vieram com algum recurso para o país ou imigrantes operários que se 
tornaram empreendedores (Barbosa, 2006; Brandão, 2009; Bresser, 2002; Cano, 1975; Dean, 1976; Silva, 1976).

Ao pesquisar o estado de São Paulo, Marson (2012) identificou que as empresas de máquinas, oficinas mecânicas e fundições em 1873, em sua maioria, faziam parte de um núcleo urbano artesanal. A maioria dos produtores tinha relações com alguma profissão artesanal do local onde estavam situados, como torneiro, carpinteiro, ferreiro, marceneiro, maquinista, e outros. Alguns desses produtores eram artesãos de origem germânica, resultado de uma imigração anterior à "imigração em massa" incentivada pela cafeicultura. Havia pouca relação desses produtores com o comércio importador e com as fazendas exportadoras. Já em 1891, as empresas da indústria de máquinas, oficinas mecânicas e fundições no estado de São Paulo apresentaram muitas ligações com o comércio exterior. Muitas das empresas presentes no setor em 1891 além de produzirem algumas máquinas, também as importavam. Essas empresas eram "casas de importação" de propriedade de imigrantes comerciantes, que controlavam o comércio, a distribuição e o financiamento das máquinas importadas. Essa relação das empresas da indústria de máquinas e equipamentos com o comércio importador irá diminuir ao longo da década de 1890 (Marson, 2012).

A produção da indústria mecânica surgiu da necessidade de fornecer assistência técnica para as máquinas que importavam, com o reparo e o fornecimento de peças e algumas máquinas inteiras. As empresas ligadas a imigrantes comerciantes foram predominantes até o início da década de 1890, e só algumas estavam ligadas diretamente a cafeicultores, como empreendedores, sendo que estes últimos fundaram poucas empresas. Entretanto, ao longo da década de 1890 muitos fazendeiros ligados ao café contribuíram para a expansão e crescimento de firmas de máquinas e equipamentos fundadas por imigrantes que abriram o capital e tornaram-se sociedades anônimas no início da década de 1890 . A forma de contribuição dos fazendeiros foi através de compra de ações e aquisição do controle de companhias que principalmente produziam máquinas de beneficiamento de café.

Nesta década encontramos ainda fundações de muitas empresas, aparentemente sem ligação com o comércio exterior (importação e exportação), de imigrantes que possuíam algum conhecimento técnico de mecânica e metalurgia. Na maioria, essas empresas fundadas entre a última década do século XIX e início do século XX, além de não terem ligações com o comércio importador, também não surgiram para atender diretamente o setor cafeeiro, e sim para atender um mercado específico local ou regional. As empresas atenderam a necessidade de máquinas para o beneficiamento da mandioca, máquinas para a indústria alimentícia (para fabricar massas), para o beneficiamento e limpeza do arroz, sem contar as de beneficiamento do algodão e da indústria da cana-de-açúcar, principal- 
mente no interior do estado de São Paulo, e da necessidade de máquinas e acessórios para a indústria têxtil, de papel, papelão, borracha e outras indústrias de bens de consumo, sobretudo na capital paulista.

Apesar de não ter ligações diretas com surgimento de algumas empresas de imigrantes mecânicos, o setor cafeeiro incentivou o movimento econômico geral que aumentou as necessidades para máquinas de outros setores. A maioria das cidades onde localizamos a fundação de empresas que produziam máquinas para outros setores estava ligada economicamente à prosperidade do café. Certamente o desenvolvimento de economias locais impulsionadas pela economia do café criou demanda e necessidade de outras máquinas. A princípio, essas empresas nasceram para atender uma demanda local e às vezes muito peculiar, ou seja, uma produção com características semi-artesanais, no sentido de que não empregavam uma linha seriada de produção. Outro fato é que mesmo em mercados pouco especializados, como o de máquinas de beneficiamento de café e algodão, havia uma grande variedade de máquinas, com diferentes preços.

\section{As transformações entre 1920 e 1980}

Como visto na seção anterior, a gênese da indústria de bens de capital, principalmente da indústria de máquinas e equipamentos brasileira, está ligada à economia agrícola. Entre 1920 e 1930 ocorreram mudanças na pauta de produtos produzidos pelas firmas de máquinas e equipamentos. A maioria das empresas fundadas na década de 1920 produzia para atender a demanda industrial, indicando uma diversificação no setor, ao contrário das fundadas antes de 1919 que atendiam em sua maioria à agricultura.

A diversificação, a partir de 1922, deu-se na área de produção de máquinas para tecelagem, cerâmica, padaria, calçados, olarias, estamparias, fabricação de macarrão e pão, máquinas para metalurgia, indústria têxtil em geral, fábricas de vidros, motores, caldeiras a vapor (Marson, 2012, pp. 99-118).

No final da década de 1930 já havia um núcleo industrial de máquinas para vários setores da indústria e também foi nesse período que se formou um núcleo de produtoras de máquinas operatrizes. Elas tiveram origem tanto nas que produziam máquinas para a indústria como nas que produziam máquinas para a agricultura. E esse núcleo que se formou no final da década de 1930 será importante para o estágio mais avançado do processo de industrialização nas décadas posteriores.

A crise de 1929 não foi a responsável pela mudança na diversificação da produção da indústria de bens de capital, já que ela inicia-se ainda no começo dos anos 1920. Entretanto, os efeitos da depressão ao longo dos anos 1930 com o aumento das atividades voltadas para o mercado interno 
foram responsáveis pela intensificação na diversificação da produção e na formação de um núcleo produtor de máquinas-ferramenta, produtos mais especializados e intensivos em tecnologia da indústria de bens de capital, como tornos, fresas, prensas, entre outros. Os efeitos da segunda guerra mundial, com a diminuição do comércio e o esforço de guerra dos países, causam a diminuição da oferta de bens de capital dos mercados europeus e norteamericanos para a América Latina. Assim, nesse período há um desenvolvimento da indústria metal-mecânica por meio de cópia de máquinas instaladas antes da guerra. Esse movimento de substituição de importações resultou em organização empresarial de "grupos econômicos", empresas juridicamente independentes, que operavam em diversos setores industriais com grande poder de mercado, sob controle de grupos de famílias. O objetivo dos grupos econômicos era satisfazer o mercado interno, embora nem sempre aproveitando-se de economias de escala. Outra característica dos grupos econômicos era a estreita relação com o Estado, tendo a estratégia de política de industrialização da América Latina a seu favor (Valdaliso e López, 2007, pp. 390-391). No Brasil, essa relação vai aparecer no Plano de Metas, em 1956, e principalmente no Segundo Plano Nacional de Desenvolvimento, em 1974 (ver Lessa, 1998, pp. 19-26, 116-120, 138-148, 246-248).

Em 1978, o Brasil era o décimo terceiro maior produtor de máquinas-ferramenta do mundo, fabricando 330000000 de dólares, sendo 4\% (12 000000 de dólares) destinados para o mercado externo. O país aparecia como o décimo consumidor mundial de máquinas-ferramenta, ou seja, era um importador líquido de máquinas-ferramenta, importando 130000000 de dólares. Em termos de produção, a Alemanha era o primeiro produtor mundial (3 188 milhões de dólares), o segundo era o Estados Unidos (3 088 milhões de dólares), e em terceiro lugar estava a União Soviética (2 543 milhões de dólares) (Jornal do Brasil, 12 de fevereiro de 1979, p. 15).

Após examinar brevemente a evolução da indústria de máquinas e equipamentos no Brasil entre o final do século XIX até os anos 1970, em seus aspectos gerais, a próxima seção foca a evolução de duas empresas importantes do setor atualmente, a Romi e a Weg.

Estudos DE CASO: RoMI E WeG

\section{História da Romi}

Américo Emílio Romi (1895-1959) nasceu na última década do século XIX, na cidade de São José do Rio Pardo (estado de São Paulo), filho de imigrantes italianos, do norte da Itália. Em 1912, Américo Emílio Romi e sua 
família, que vieram para o Brasil motivados pelo trabalho nas fazendas de café do interior do estado de São Paulo, retornam para a Itália. O pai de Emílio Romi tinha conhecimentos de mecânica e trabalhou na construção da ponte metálica sobre o rio Pardo, com Euclides da Cunha, em 1896. Em 1900, a família mudou-se para Casa Branca e seu pai conseguiu empregar-se como maquinista da Cia. Mogiana de Estrada de Ferro, permanecendo no emprego até 1906. Depois desse período, a família acumulou algum dinheiro e resolveu voltar para a Itália para proporcionar educação para seus filhos. Na Itália, em 1912, Américo Emílio estudou eletromecânica e começou sua atividade profissional como mecânico na fábrica da Tecnomazio Brown-Boveri, em Milão. A partir de 1915, Romi serviu na primeira guerra mundial consertando caminhões e veículos militares para a Itália, revelando suas habilidades mecânicas. Romi voltaria para o Brasil em 1923 para trabalhar como mecânico em um revendedor Ford, em Santo Amaro (Revista Exame, 1973, pp. 51-52; Visão, 1961, pp. 22-23).

Em 1924, Emílio Romi mudou-se com a família para a Vila Americana, que pertencia ao município de Piracicaba, em busca de novas oportunidades de trabalho. Com suas habilidades em mecânica encontrou emprego em uma oficina Chevrolet, onde adquiriu grande número de clientes e passou a ganhar o maior salário de mecânico da região. Entre 1927 e 1929, Romi mudou-se novamente, agora para Santa Bárbara do Oeste (Revista Exame, 1973, pp. 51-52).

No final do ano de 1929, Romi iniciou seu próprio negócio com um capital de apenas dois contos de réis que foi emprestado por um amigo. Nasceu a Garage Santa Bárbara de Emílio Romi, uma firma de propriedade individual, com apenas dois operários em uma área de duzentos e cinqüenta metros quadrados. Logo depois da fundação, antevendo os efeitos da crise de 1929 sobre as importações, Emílio Romi comprou uma grande quantidade de peças para automóveis, tornando-se a maior oficina mecânica da região (Revista Exame, 1973, pp. 51-52; Romi, 1970a, p. 2, e 1970b, p. 66).

Apesar dos efeitos da crise de 1929, ao longo da década de 1930, a Romi teve expansão significativa, resultando em mudanças importantes no processo de produção e nos produtos produzidos. Em 1929, além de consertar automóveis, a empresa de Emílio Romi reparava arados e semeadeiras estrangeiras, produzindo peças para esses produtos. Em 1932, Romi passou de oficina de reparos para a fabricação de máquinas agrícolas. No final de 1933 e início de 1934, os jornais de Santa Bárbara (Cidade de Santa Bárbara e $O$ Bandeirante) noticiaram a inauguração da nova seção de mecânica e fundição das oficinas Romi anexa à garagem e à oficina de marcenaria já existente. A fundição era de grande porte e moderna para a cidade no período e estava aparelhada para fabricar quaisquer peças de máquinas 
exigidas pela indústria local e das cidades vizinhas. A fundição era composta de duas fornalhas, uma para a fundição de ferro e outra de bronze, com capacidade de produção de 150 toneladas de peças fundidas por mês. Estava resolvido o problema da fundição de peças de ferro e bronze. Em 1936, Romi comprou seu primeiro torno mecânico iniciando o aparelhamento do seu maquinário com a expansão do mercado nos anos 1930 ( $O$ Bandeirante, 1934; Revista Exame, 1973, p. 52; Santa Bárbara, 1933).

Em 1937, a Fábrica de Máquinas Agrícolas Santa Bárbara era uma das unidades industriais mais importantes daquele município. A empresa possuía setenta e cinco operários em comparação aos quatro mecânicos que iniciaram em 1929, e sua produção anual de máquinas era de quase seiscentos contos de réis (Santa Bárbara, 1937). Em 1938, a firma Américo Emílio Romi tornou-se sociedade limitada, denominando-se Máquinas Agrícolas Romi Ltda., com um capital de trezentos contos de réis. Em 1939, a empresa era a maior fábrica de máquinas agrícolas do Brasil, possuindo prensas de grande tonelagem para a produção dos equipamentos. Seus produtos eram fabricados com métodos modernos, semelhantes às grandes organizações industriais do Estados Unidos e Europa. Os produtos eram vendidos aos mais modernos agricultores do país e exportados para países do continente americano (Diário de São Paulo, 1939, p. 4; Revista Exame, 1973, p. 52).

Durante a segunda guerra mundial, com a interrupção das importações, a Romi decidiu especializar a sua produção e produzir um novo produto, o torno. A Romi iniciou a produção de tornos mecânicos em 1941. A produção de tornos mecânicos foi intensa e já em 1943 a firma havia produzido 1000 unidades. A empresa adotou a estratégia de investir no setor de tornos mecânicos e abandonou a produção de máquinas agrícolas, evitando assim uma diversificação prematura. Para reforçar e manter a especialização a empresa iniciou a exportação desse produto para a América Latina. Em 1946, a Romi exportava em média 40 tornos por mês para a Argentina, atingindo uma grande participação nesse mercado.

Em 1948, com o auxílio do engenheiro André Toselo, a Romi iniciou a produção do primeiro trator nacional, denominado Toro, baseado no modelo Allis-Chalmers triciclo. Esse trator era mais pesado e mais potente do que seu concorrente direto, tendo um preço maior do que o modelo da Ford. O preço do primeiro trator nacional inviabilizou seu projeto e a Romi manteve-se afastada do mercado de veículos automotores até 1954, quando a empresa adquiriu os direitos de fabricar o automóvel Isetta da Iso-Motor, de Milão, Itália. O Romi-Isetta, primeiro automóvel nacional de dois lugares, com apenas 30\% das peças importadas, foi fabricado até 1959, mas o projeto foi encerrado pela empresa porque a política de apoio às empresas automobilísticas pelo Grupo Executivo das Indústrias Automobilísticas para a isenção de impostos para a importação de peças excluiu 
os automóveis de dois lugares. Assim, seu custo inviabilizou seu sucesso no mercado automobilístico nacional, já que as peças de automóveis de quatro lugares tinham isenção de imposto e taxa de câmbio diferenciada para a importação de peças (Banas, 1970, pp. 7-12; Revista Exame, 1973, pp. 52-54; Romi, 1970a; Romi, 1970b, pp. 66-67).

Na década de 1960 a Romi tornou-se uma das principais empresas produtoras de torno do mundo, ficando atrás apenas de uma empresa estatal da União Soviética. No final da década de 1960, a empresa exportava tornos para diversos países, inclusive da Europa, Japão e Estados Unidos. A empresa vendia tornos com tecnologia local inclusive para uma firma de Cincinatti, região onde se concentravam as três maiores empresas produtoras de torno do Estados Unidos no final dos anos 1960 (Banas, 1970, pp. 7-12; Revista Exame, 1973, pp. 52-54; Romi, 1970a; Romi, 1970b, pp. 66-67).

\section{O processo de internacionalização da Romi}

Atualmente, a Romi possui onze fábricas com capacidade de produção de 3450 máquinas por ano. Seus principais mercados são máquinas-ferramenta e máquinas para processamento de plástico. Possui cerca de 6000 clientes ativos em mais de 60 países, que atuam no setor automotivo, máquinas agrícolas, bens de capital, bens de consumo, ferramentaria, equipamentos hidráulicos, energia eólica e outros. Cerca de $75 \%$ do faturamento da empresa está relacionado às vendas de tornos convencionais, tornos a controle numérico computadorizado, centros de usinagem, tornos verticais e horizontais pesados e extrapesados, centros de torneamento e mandrilhadoras. Em torno de 15\% da receita vêm do setor de injetoras de plástico (Romi, 2012, pp. 6-9).

O processo de internacionalização da Romi está ligado ao movimento de exportação da empresa iniciado nos anos 1940. Com as exportações, a Romi tornou-se parceira de empresas do mercado internacional, com transferência de tecnologias. $O$ processo de internacionalização teve origem com a troca de tecnologia e as exportações. Nas exportações, a Romi utilizava distribuidores, uma escolha que diminuía o risco da atividade. Além disso, eram necessários subsidiários no exterior, pelo mercado específico de máquinas e equipamentos em que a empresa atua. Apesar de não produzir no exterior, a empresa precisava prestar serviços de assistência técnica para vender suas máquinas e equipamentos. Assim, "as subsidiárias no exterior, então, eram basicamente para armazenagem, pré-venda, venda e assistência técnica. A empresa dispunha dessas subsidiárias nos mercados do Estados Unidos, Argentina e Uruguai e estava implantando outra na Alemanha” (Veiga e Rocha, 2003, p. 169). 
O processo efetivo de internacionalização da Romi ocorreu nos anos 1990, quando a empresa começou suas operações no mercado norteamericano, em Chicago. Em 1998, a empresa transferiu suas operações para Erlanger, no Kentuchy, uma região de concentração de produtores de máquinas-ferramenta, fundando a Romi Machine Tools. Em 2001 foi criada a Romi Europa GmbH, uma subsidiária na Alemanha, para dar suporte à rede de distribuição no mercado europeu. Também para dar suporte às atividades da empresa na Europa, em 2008, foi criada a Romi Italia s.r.l., com sede em Turim, na Itália. Nesse mesmo ano, a Romi adquiriu ativos da Sandretto Industrie s.r.l., fabricante de injetoras de plástico, com fábricas localizadas em Grugliasco e Pont Canavese, na região de Turim, Itália. A Romi continuou sua expansão na Itália e assinou acordo com a empresa Lazzati s.p.a., da região de Milão, para a produção de mandrilhadoras, e com a PFG s.p.a., para a fabricação de Centros de Usinagem de Coluna Móvel. Em 2010 e 2011, a Sandretto e a Romi lançaram produtos na Alemanha, França e Reino Unido. Nesse último ano, tem início as atividades da Sandretto México, operando com as marcas Romi e Sandretto naquele país. Também em 2011, a Romi adquire a Burkhardt+Weber Fertigungssysteme $\mathrm{GmbH}$, fabricante alemã de máquinas-ferramenta. Todas essas iniciativas expandiram as operações globais e de mercados da empresa (Romi, 2014).

No mapa 1 é possível visualizar as plantas industriais e as subsidiárias de vendas da Romi pelo mundo. Na tabela 1 (ver anexo) há um resumo dos investimentos da Romi em controladas e coligadas no exterior em 2012.

\section{História da Weg}

A Weg chegou em 2013 como uma empresa consolidada, tanto no mercado interno quanto externo. Além do Brasil, possuía fábricas em outros doze países e filiais comerciais em outros 24 . Seus distribuidores e agentes estavam presentes em 85 nações e mais de 1200 assistentes técnicos atuavam nos cinco continentes. Para dar conta destas atividades, contava com 29099 colaboradores (Campos, 2013). Sua receita operacional líquida foi de 6828.9 milhões de reais, sendo que o mercado interno foi responsável por 3432 milhões de reais e o externo por outros 3396.9 milhões de reais, $50 \%$ da receita em cada um. O lucro líquido atingiu 843500000 reais e os investimentos no ano somaram 243700000 reais, sendo 80\% destinados aos parques industriais e demais instalações no Brasil e o restante às unidades produtivas e demais subsidiárias no exterior (Weg, 2013).

Em 1961, esta firma iniciou modesta, na cidade de Jaraguá do Sul, em Santa Catarina, região de colonização alemã, à época, com cerca de 20000 habitantes. O nome originalmente adotado foi Eletromotores Jaraguá Ltda. e 


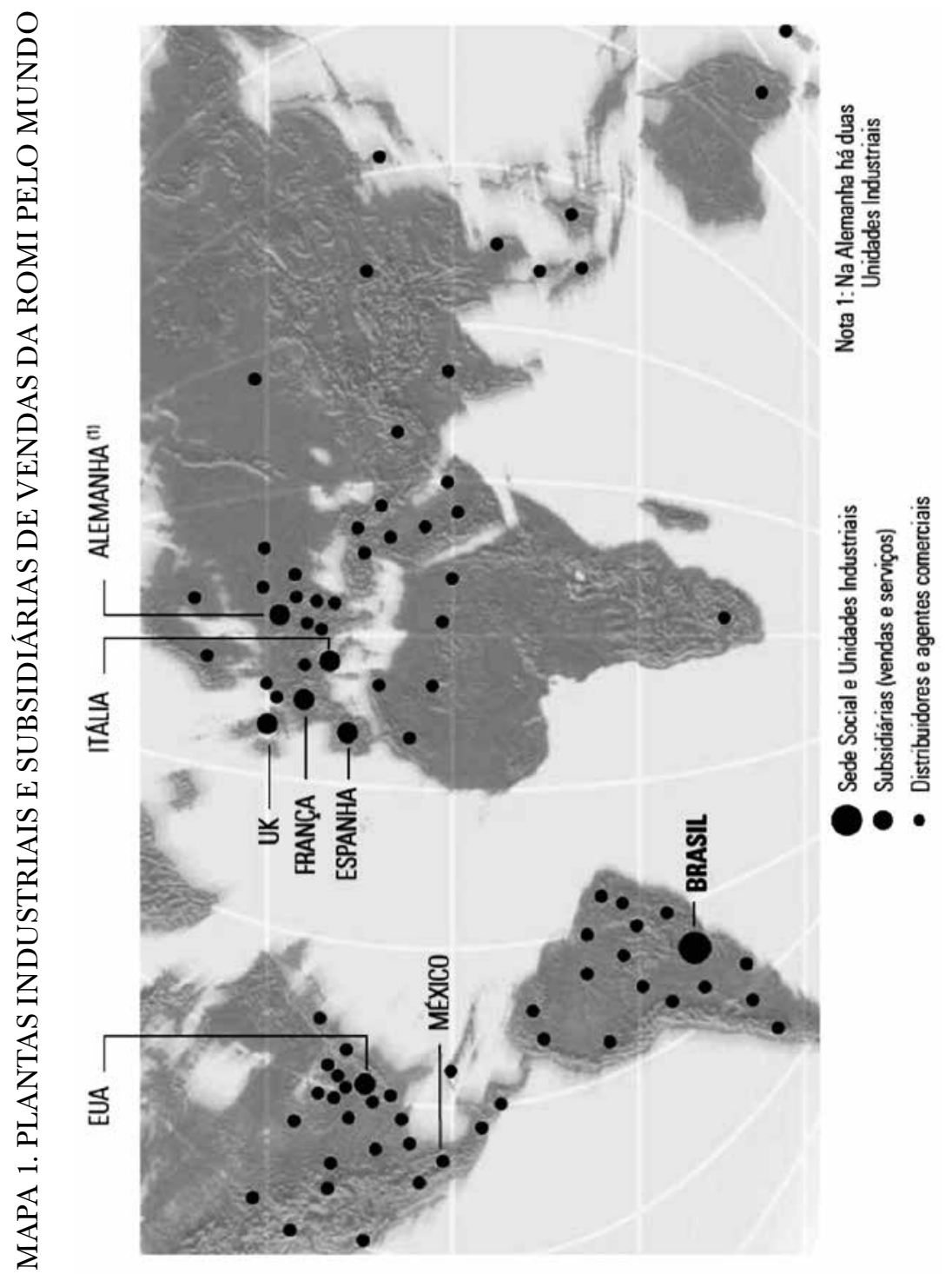

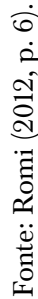


o atual, WEG, é a combinação das primeiras letras do nome dos fundadores (o eletricista Werner Ricardo Voigt, o administrador Eggon João da Silva e o mecânico Geraldo Werninghaus). Há diversos autores que estudaram e relataram a história da empresa, tanto no mercado interno como seu processo de internacionalização. Entre eles, podem ser mencionados: Schiavini, Scherer e Moura (2011); Mello Dias, Caputo e Marques (2012); Predebon (2010); Floriani, Borini e Fleury (2009); Chataque (2004); Weg (2001). Nós seguimos, no geral, o relato destes autores, com destaque para Melo (2010 e 2013).

O capital inicial foi de 3600 cruzeiros, que equivalia a cerca de 11726 dólares. A companhia iniciou suas atividades de fabricação de motores elétricos num imóvel alugado, de cerca de 200 metros quadrados, na avenida Getúlio Vargas 667, onde atualmente encontra-se o Museu Weg.

Em 1963 os fundadores decidiram ampliar o negócio criando outras duas empresas: a Saweg, para produção de transformadores domésticos e a Nina, para produzir máquinas de lavar roupa. Entretanto, em 1967 ambos os empreendimentos foram desativados. Em 1964 foram inauguradas as próprias instalações, e em 1968 foi criado o Centro de Treinamento, onde jovens e adultos passaram a ser formados em cursos profissionalizantes, para suprir a falta de qualificação da mão-de-obra na região.

As décadas de 1960 e 1970 foram de forte crescimento na economia nacional e a Weg aproveitou o momento para crescer, diversificar produtos e atender as novas demandas. Para tanto aumentou sua capacidade produtiva de 63000 motores, em 1971, para cerca de 1000000 em 1980. Seu número de funcionários acompanhou o crescimento, passando de 476 para 3 542, nas mesmas datas.

Em 1974, a Weg inaugurou outro parque industrial gerando 600 novos empregos e dobrando sua capacidade de produção. Nos anos 1980 a empresa enfrentou a crise, a inflação, o baixo crescimento reduzindo a jornada de trabalho e investindo na qualificação de seus operários. Além disso, ampliou a diversificação, constituindo a Weg Acionamentos, a Weg Transformadores, a Weg Máquinas, a Weg Química e a Weg Automação.

Na década de 1990, com novo presidente executivo, a Weg empreendeu uma estratégia de disputar o mercado nacional e voltou-se para o exterior como uma maneira de manter-se crescendo e conquistando novos clientes, novos mercados e buscando novas tecnologias.

Como vimos no início desta seção, em 2013 a Weg estava consolidada tanto no Brasil como no mercado internacional e atuava em cinco linhas principais de produtos: motores, energia, transmissão e distribuição, automação e tintas. Produz tanto motores padronizados como está capacitada para desenvolver outros produtos sob encomenda dos clientes. Seu faturamento está dividido meio a meio entre o mercado nacional e o internacional, como veremos na próxima seção. 
O processo de internacionalização da Weg

A Weg deu início a seu processo de internacionalização no começo dos anos 1970 quando aconteceram as primeiras exportações para países vizinhos da América Latina. As vendas externas começaram pela busca dos produtos Weg por parte dos consumidores-clientes e, pelo lado da empresa, para conquistar novos mercados. No entanto, o início do processo foi lento, desarticulado e a firma só chegou a ter metade de seu faturamento no mercado externo depois de atravessar diversas fases, como descreveremos a seguir.

Primeira fase da internacionalização da Weg: exportações na década de 1970

De acordo com Melo (2010), “a primeira exportação data de 1970” (p. 67). ${ }^{1}$ No entanto, ela ocorreu mais de forma casual que planejada. Consumidores latino-americanos, de países como Paraguai, Uruguai, Equador e Bolívia mostraram interesse nos produtos e a Weg passou a atender essa demanda. Melo (2010), baseada nos registros do Museu da Weg, afirma que o Paraguai consta como primeiro destino das exportações. Enquanto estas vendas eram esporádicas, não havia preocupação em montar uma estrutura para esta finalidade. No entanto, na medida em que foram aumentando as exportações surgiu a necessidade de organizar um setor que não só atendesse os pedidos, mas que servisse para impulsionar as vendas internacionais.

Quando a empresa decidiu montar um setor específico voltado às exportações, também surgiram as primeiras dificuldades. De acordo com Silva (2011), entre as barreiras enfrentadas nesta fase, podemos destacar: a) dificuldade em estabelecer distribuidores no exterior, porque a Weg não era conhecida. A solução veio através do contato com pessoas no exterior, interessadas na venda e assistência técnica dos produtos Weg. No Paraguai, por exemplo, a Record Electric do Paraguai ficou encarregada da venda e assistência técnica. A vantagem é que ela tinha facilidade com o idioma, conhecia os aspectos culturais, bem como as barreiras inerentes à importação, documentos, frete e assistência pós-venda. Outra atitude proativa da Weg foi a participação de feiras internacionais com o intuito de divulgar seus produtos; $b$ ) a segunda dificuldade na medida em que aumentavam as vendas externas era com a padronização dos produtos. Era necessário vender um motor que estivesse em consonância com as normas

\footnotetext{
${ }^{1}$ Nesta parte do texto seguimos o relato do processo de internacionalização feito por Melo (2010, pp. 67-77).
} 
internacionais. A Weg adaptou-se às condições da International Electrotechnical Commission e comprou tecnologia na Alemanha para produzir os primeiros motores dentro das normas.

Desta maneira pode-se afirmar que o início das exportações se deu através do estabelecimento dos primeiros representantes, da busca de novas tecnologias para adaptação dos produtos e com baixa participação da Weg no exterior.

Segunda fase da internacionalização da Weg:

a conquista dos mercados nos anos 1980

A segunda fase caracteriza-se pelo aumento da rede de representantes em diversos países. Neste caso, a dificuldade maior era encontrar assistentes técnicos para o serviço pós-venda. Como os especialistas em motores normalmente prestavam serviços a concorrentes estabelecidos há mais tempo, a Weg precisou encontrar novos assistentes, investir em seu treinamento e lhe oferecer condições para desenvolver seu trabalho.

Na década de 1980, segundo Silva (2011), foi criado o Departamento de Comércio Exterior, encarregado de manter contato com o mercado internacional, assim como pensar todo processo de envio de produtos e assistência técnica. A participação sistemática em feiras internacionais foi incorporada ao comportamento da firma no intuito de tornar a marca conhecida. Na medida em que aumentavam as vendas externas a Weg foi encontrando soluções como, por exemplo, encontrar distribuidores que montassem um estoque mínimo para atender com mais agilidade a demanda.

Apesar do evidente avanço em relação à década anterior, ainda havia problemas persistentes a serem superados como: $a$ ) dificuldade de ter funcionários que falassem com fluência o inglês. Para tanto a empresa incentivou o aprendizado interno; $b$ ) os funcionários não sabiam como funcionava, na prática, a venda e assistência no exterior. Resolveu enviar empregados nas filiais externas para um período de treinamento; $c$ ) para superar as barreiras da língua, cultura, forma de fazer negócios e prestar assistência técnica, a empresa contratava funcionários dos respectivos países, sempre que possível; $d$ ) deixar de exportar só o que sobrava do mercado interno. Como ainda não havia uma "cultura de exportação" ou uma "cultura de internacionalização", muitas empresas nacionais só exportavam o excedente. A Weg decidiu que "exportar faz parte do nosso negócio" e preparou um planejamento da produção que pudesse atender tanto o mercado interno como o externo. Surgiu, neste momento, a Weg Exportadora com a preocupação, não só de aumentar as vendas, mas de atender as especificidades dos negócios de cada país. 
Pode-se dizer que nesta fase a Weg ainda se caracterizava por manter representantes e distribuidores, com o diferencial que o número de países era crescente. Como os representantes passaram a se fixar nos países da América Latina e Europa, tanto o espanhol como o inglês passaram a ser línguas necessárias. Houve ainda o desenvolvimento de produtos padronizados com as exigências do comércio internacional e uma presença sistemática nas feiras do setor.

Terceira fase da internacionalização da Weg: novo impulso nos anos 1990

Iniciou com a definição clara de uma estratégia de atuação no mercado externo e a instalação de filiais comerciais próprias. Num primeiro momento, no Estados Unidos, a Weg Electric Motors, e na Bélgica, a Weg Europe, buscaram atender os mercados regionais. No entanto, logo percebeu-se a necessidade de estabelecer filiais próprias nos principais países do exterior cujo mercado fosse forte o suficiente para justificar tal presença. Com esta decisão, diversas filiais foram instaladas no Estados Unidos, Bélgica, Argentina, Japão, Alemanha, Austrália, Inglaterra, México, Espanha, França, Suécia (Silva, 2011), chegando, em 2013, ao número total de 24 países com filiais comerciais próprias (ver figura 1).

Na década de 1990 o Departamento de Comércio Exterior foi extinto, substituído pela Weg Exportadora, constituída como uma empresa a parte. Para atender melhor um número crescente de filiais comerciais, iniciou um processo de expatriação de executivos encarregados da gestão dos negócios no exterior.

Assim como nas fases anteriores, nesta também foi necessário superar uma série de barreiras, tais como: $a$ ) a primeira dificuldade veio em relação aos representantes. Como a Weg tinha interesse em divulgar e vender todos seus produtos e não apenas os motores, diversos representantes, satisfeitos com os seus lucros, não tinham interesse em aumentar e diversificar as vendas. A empresa decidiu, então, substitui-los por filiais comerciais próprias que passaram a ser instaladas sucessivamente (ver figura 1); b) descobrir a melhor maneira de implantar uma filial comercial própria no exterior. Para tanto, houve desde associação com distribuidores locais até a compra pura e simples dos concorrentes. $\mathrm{O}$ mais difícil foi resolver a parte contábil e legal, pois cada país possui a própria legislação. Para tanto a Weg contratou especialistas locais em cada país; c) sobretudo nos primeiros anos de atuação externa, era preciso mudar a imagem do Brasil, considerado país pobre e de "terceiro mundo". Buscando solucionar o problema, a Weg adotou a prática de trazer clientes e 


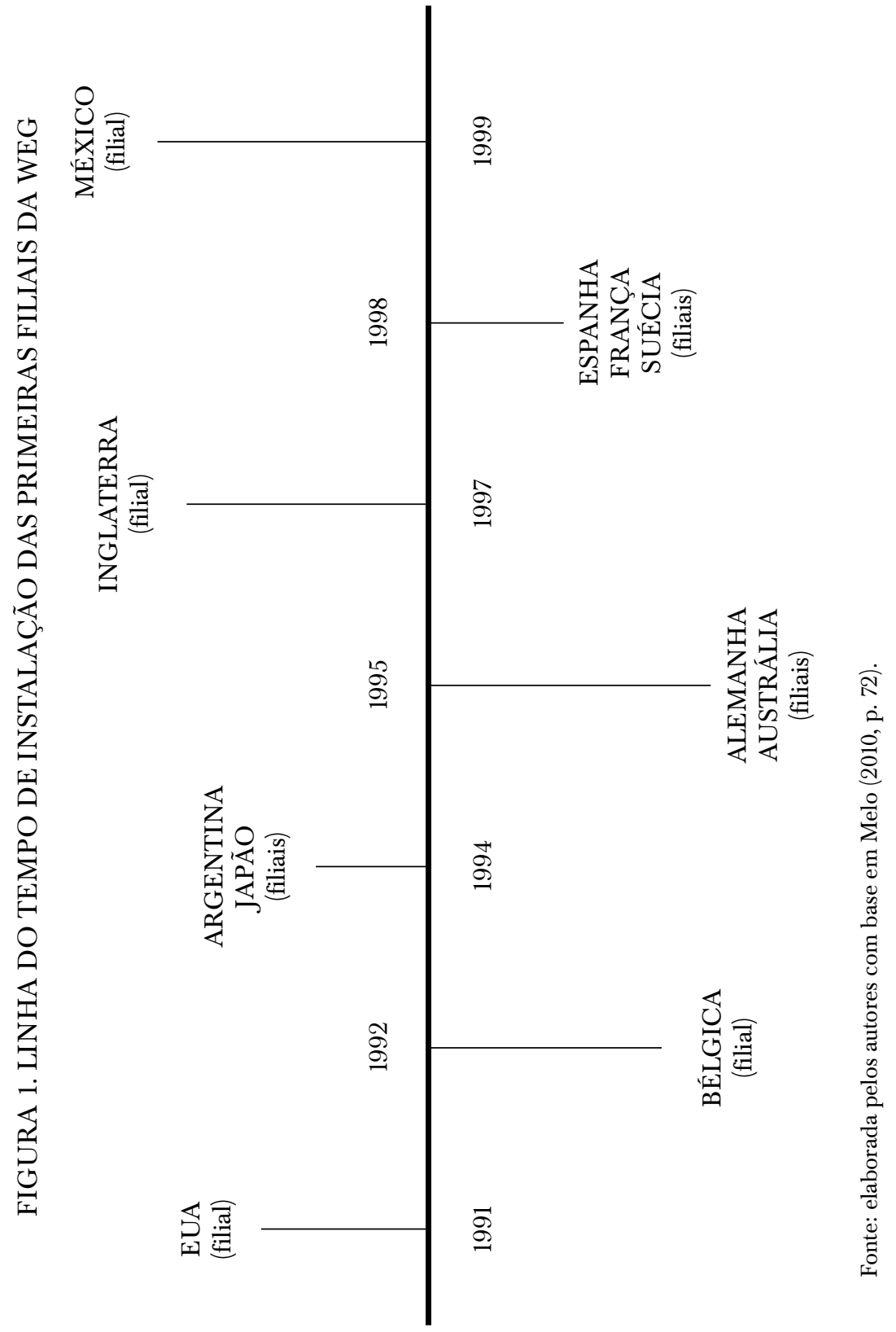


potenciais clientes para visitar o Brasil e a sede da empresa. Melo (2010, p. 73) cita a cifra de 1100 visitantes por ano que vêm ao Brasil. Esta troca de experiências entre os funcionários da Weg no Brasil e os visitantes ajudou a melhorar tanto a imagem da empresa no exterior como aprimorou o aprendizado dos futuros expatriados da firma.

Podemos afirmar que essa fase foi a mais produtiva no processo de internacionalização pelo fato de estabelecer bases sólidas no cenário internacional, sobretudo via atuação com filiais comerciais. Entretanto, a fase mais desafiadora viria logo em seguida, com a implantação ou aquisição de plantas industriais no exterior.

Quarta fase da internacionalização da Weg:

a implantação industrial no exterior

A fase de implantação industrial no exterior começou pelo país vizinho, a Argentina. De acordo com Floriani, Borini e Fleury (2009) a motivação foi a necessidade de atender o mercado argentino de forma mais proativa. Em 1994, a Weg estabeleceu uma joint-venture com uma empresa argentina, que durou dois anos. Esta experiência trouxe um novo aprendizado, em relação aos aspectos regulatórios locais. Conforme leis trabalhistas argentinas, a Weg precisou defender-se judicialmente do passivo trabalhista que sua ex-associada deixou. Em virtude disso decidiu comprar concorrentes e não mais fazer associações. Após esta primeira experiência, em 2000, a Weg adquiriu duas empresas argentinas: uma planta em Córdoba, para produção de motores e outra em Buenos Aires, para fabricação de disjuntores.

Nesta fase de internacionalização, pode-se destacar objetivos diferenciados conforme o país. No caso argentino, a fábrica é de motores para lavadoras, uma atividade complementar, uma vez que a Weg não fabrica este produto no Brasil e passou a representar uma diversificação. A aquisição em Portugal seguiu lógica semelhante de complementação de produtos, uma vez que a Weg não fabricava motores pré-classificados para área de risco. ${ }^{2}$ A compra da fábrica significou o acesso imediato da firma à fabricação destes motores.

A primeira planta industrial do México foi comprada em 1999 com a finalidade de expandir o mercado tanto para aquele país como para Esta-

\footnotetext{
${ }^{2}$ Área de risco é, por exemplo, um motor para acionar a bomba de gasolina. Em caso de dano, este motor poderia gerar faísca, queimar ou explodir. Os motores fabricados para área de risco são produzidos conforme normas próprias para este tipo de ambiente e credenciados pelos respectivos órgãos.
} 
dos Unidos e Canadá. Em 2013, as três fábricas do México representavam a maior presença internacional da companhia, empregando 1232 funcionários (ver tabela 2 , anexo).

A conquista do mercado asiático deu-se em função da grande possibilidade que oferecia. De acordo com Melo (2010, p. 74), na Índia havia uma oferta de 40 fabricantes de transformadores, enquanto que em outros países este número não passa de três ou quatro. Além do mais tanto a China como a Índia são dois grandes mercados e com um crescimento econômico bem acima da média mundial, sem contar a possibilidade de atender à demanda dos demais países asiáticos (ver figura 2).

As principais barreiras enfrentadas pela Weg nesta fase podem ser resumidas da seguinte forma: a) descobrir a maneira mais adequada de implantar uma fábrica no exterior. Aqui trata-se de descobrir se é melhor construir ou comprar uma concorrente. A Weg adotou as duas medidas (aquisição de sete plantas e construção de três) (ver tabela 2, anexo), conforme as oportunidades e as melhores soluções encontradas para cada país; b) descobrir o jeito mais eficiente de implantar a cultura Weg nas plantas industriais estrangeiras. Para minimizar este problema a firma enviou brasileiros para estagiar nas fábricas do exterior e, no sentido inverso, trouxe estrangeiros para participar de treinamentos na Weg Brasil.

A figura 3 resume as várias fases do processo de internacionalização da firma. A tabela 2 (ver anexo) ajuda a compreender os estágios três (implantação de filiais comerciais) e quatro (construção e/ou aquisição de plantas industriais) no processo de internacionalização da Weg, com os países, as cidades, o nome das empresas, o ramo de atividade e a quantidade de trabalhadores em cada local.

O gráfico 1 possibilita visualizar como se deu o processo de internacionalização da Weg a partir das diferentes fases vividas, desde o início das exportações, da busca de novos mercados, da implantação de filiais comerciais e, por fim, da construção e aquisição de fábricas.

O mapa 2 permite visualizar a presença da Weg no mundo em 2013, com destaque para as fábricas (doze países além do Brasil) e as filiais comerciais (24 países além do Brasil).

De acordo com Mello Dias, Caputo e Marques (2012, pp. 171-172), foram duas motivações que levaram a Weg a se inserir no mercado internacional: $a$ ) aquisição de novas tecnologias, estratégia voltada para países ricos; $b$ ) aumento de participação de mercado, estratégia destinada a mercados emergentes. Na busca de novas tecnologias podem ser mencionadas as aquisições da Watt Drive, na Áustria e da Electric Machinery, no Estados Unidos, que permitiram à Weg acesso a tecnologias que ainda não dispunha e serão fundamentais para a ampliação do seu portfólio de produtos e mercados. Como exemplos de internacionalização para aumento 


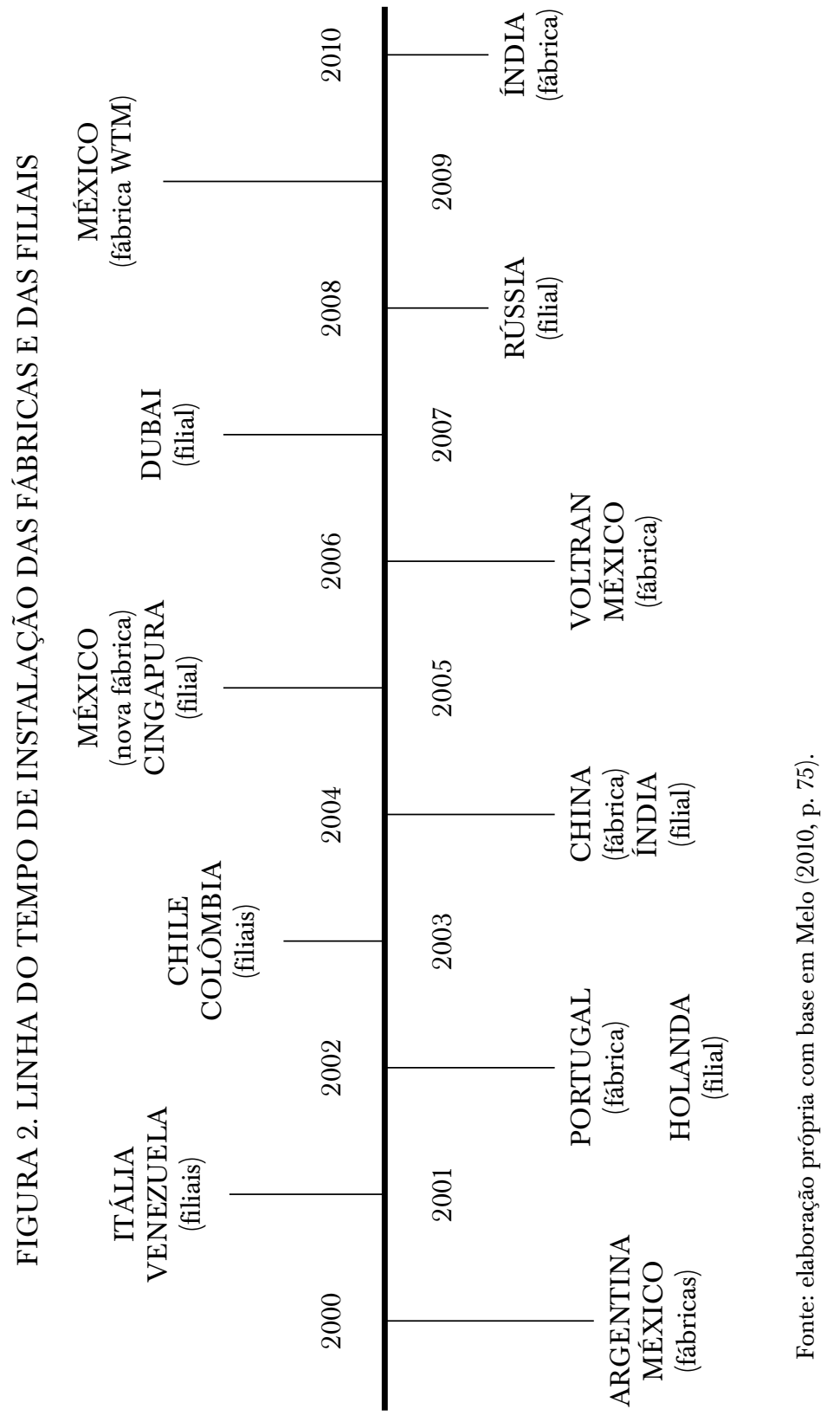




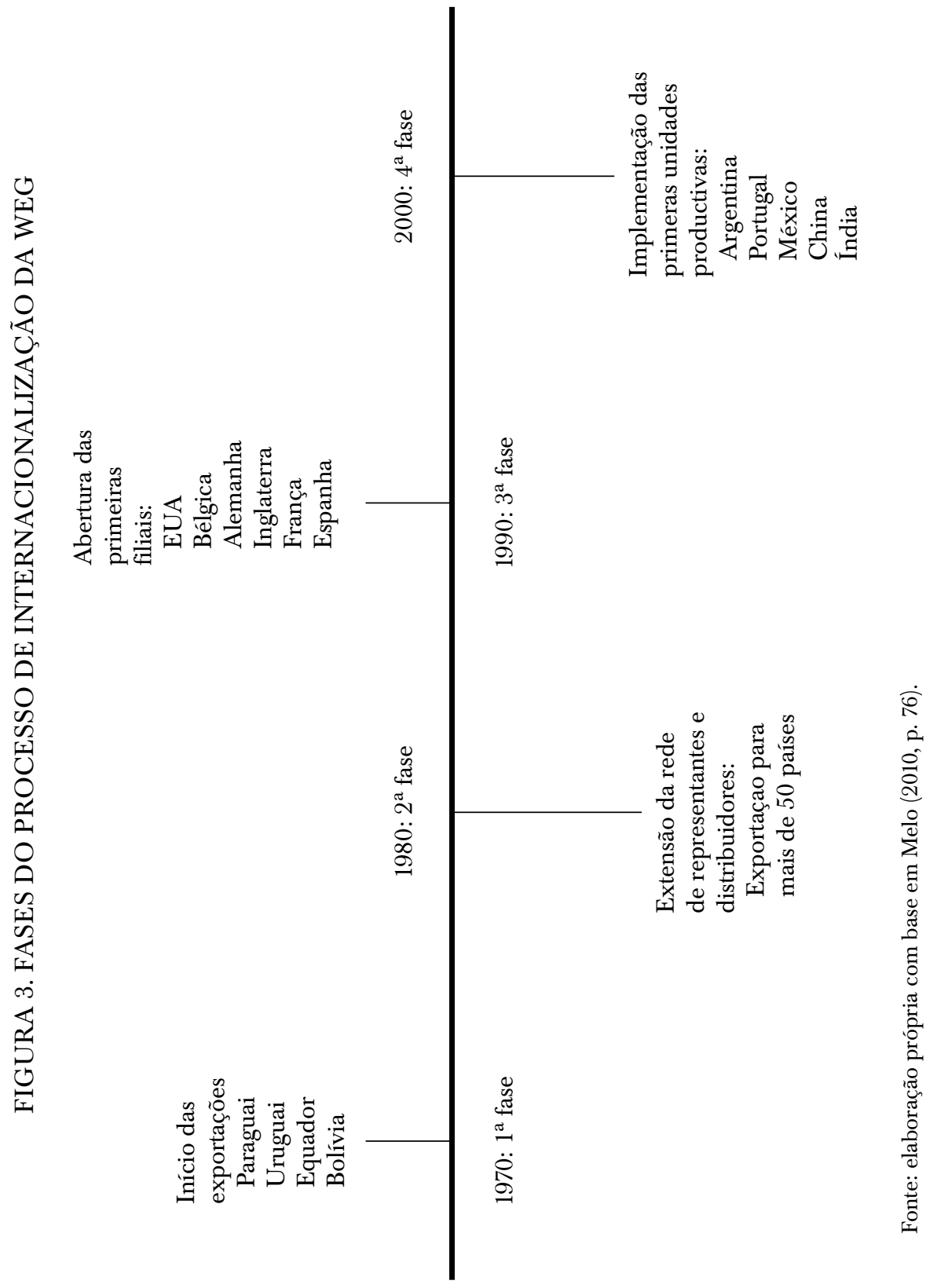




\section{GRÁFICO 1. FASES QUE REPRESENTAM O DESEMPENHO DA WEG NO EXTERIOR}

\section{Desempenho no Exterior}
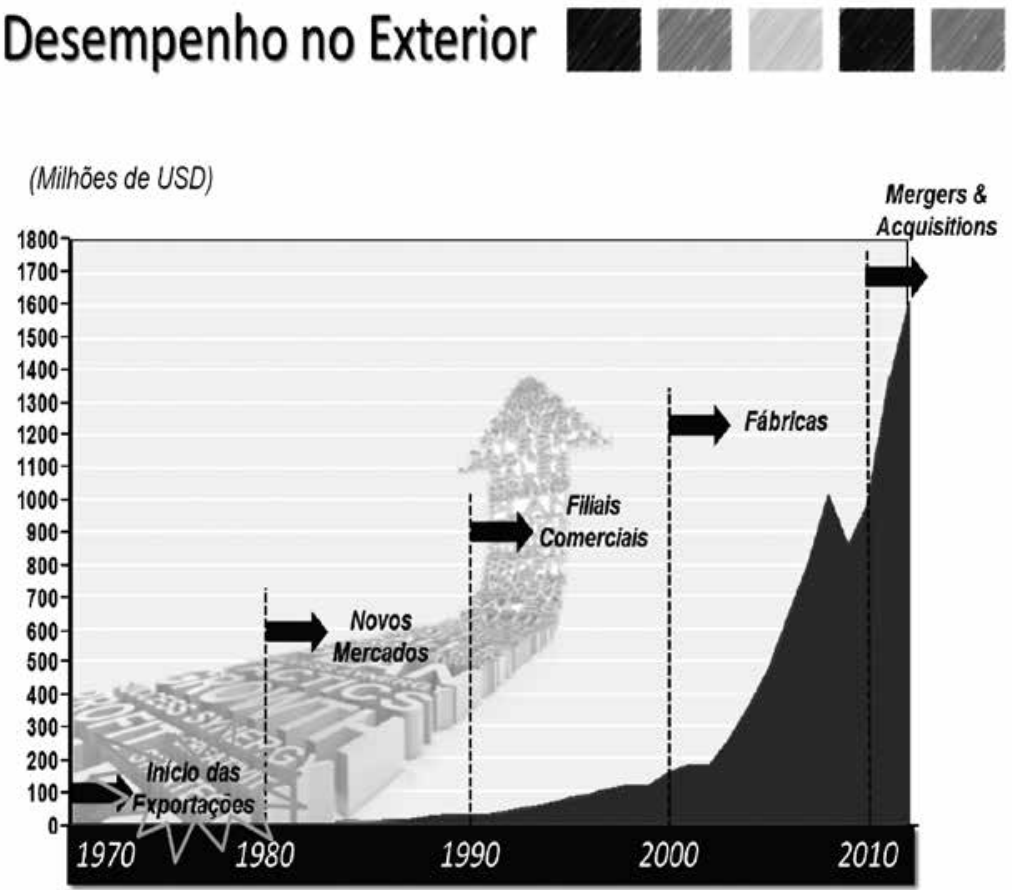

WEg

Fonte: Campos (2013).

de participação em mercados podem ser mencionadas as aquisições da Zest, na África do Sul e a construção da unidade fabril na Índia.

Outro aspecto a destacar no processo de internacionalização da Weg é em relação à sua estratégia de ampliar o market share no exterior vinculado ao fornecimento de soluções completas de energia (sistemas incluindo motores, turbinas, geradores, transformadores e automação). É a mesma estratégia já utilizada no mercado brasileiro onde a empresa tem, por exemplo, soluções completas para o segmento de pequenas centrais hidrelétricas (Mello, Caputo e Marques, 2012, p. 172).

Por fim, estes mesmos autores mencionam a forma de entrada nos mercados externos. Afirmam que a Weg utilizou tanto projetos greenfield, quanto aquisições. A estratégia utilizada depende de vários fatores e é de- 


\section{MAPA 2. PRESENÇA GLOBAL DA WEG EM 2013: FÁBRICAS, FILIAIS COMERCIAIS, DISTRIBUIDORES E ASSISTÊNCIA TÉCNICA}

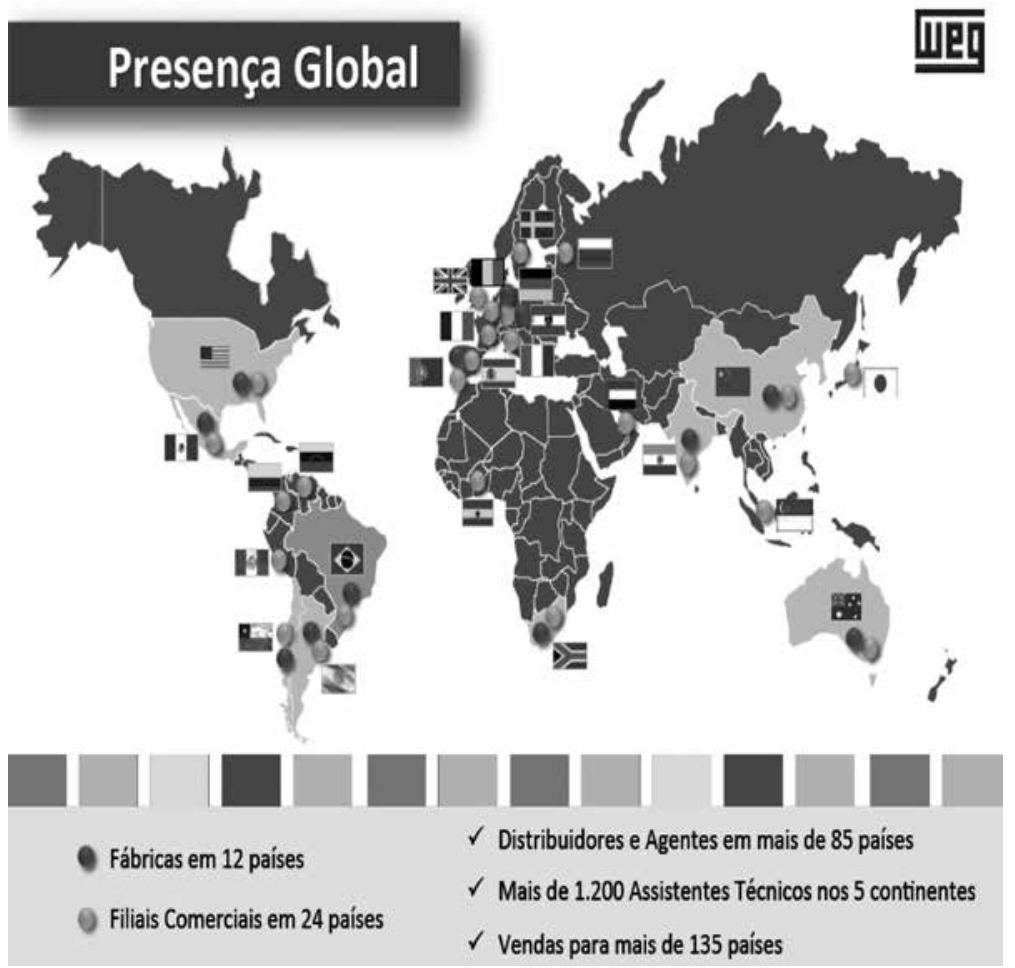

Fonte: Campos (2013).

cidida caso a caso. Em geral, o processo de atuação nos novos mercados é gradual. De início a demanda é atendida com produtos exportados do Brasil, distribuídos por representantes locais. Assim que as quantidades justificam, a empresa implanta uma filial comercial própria e, por fim, nos grandes mercados consumidores, a última etapa consiste, quando há viabilidade, na implantação e aquisição de planta industrial própria.

\section{CONCLUSÕES}

Ao longo do trabalho examinamos a evolução de duas importantes empresas da indústria de bens de capital do Brasil, a Romi e a Weg. Ambas as 
empresas, apesar do desenvolvimento atrelado ao mercado interno, começaram o processo de exportações em poucos anos após sua constituição. A Romi, fundada em 1930, exportou a partir de 1944, e a Weg, fundada em 1961, exportou a partir de 1970. Nas duas empresas a preocupação em atender ao mercado externo estava presente desde cedo, intensificada pela necessidade de aperfeiçoamento do produto que o ramo de bens de capital necessitava. As exportações das empresas podem ser vistas como um indicador de eficiência do processo de produção e do produto, já que significa que as elas atenderam ao mercado concorrencial relativamente mais exigente do que o brasileiro. As exportações também são, geralmente, a primeira etapa do processo de internacionalização.

Os casos da Romi e da Weg relatados nesse trabalho contrastam com a visão pessimista da literatura sobre o processo de substituição de importações no Brasil. Essas empresas desenvolveram as características para atender ao mercado externo diante de políticas voltadas para substituir importações. Assim, dentro de uma estrutura industrial fechada para o mercado interno, houve casos de empresas que realizaram esforços de exportações, pouco tempo após sua fundação, principalmente porque especializaram em um setor intensivo em tecnologia e necessitavam do contato externo para seu desenvolvimento.

O presente artigo remete à necessidade de novos trabalhos sobre história de empresas para entender melhor o processo de industrialização por substituição de importações, geralmente fundamentado em análises macroeconômicas que enfatizam a baixa capacidade de geração de exportações dos países da América Latina, resultando em crises do Balanço de Pagamentos. Pelo exame micro, da história de empresas, encontramos casos de sucesso de empresas em um setor intensivo em tecnologia, como o de bens de capital. A Romi, nos anos 1960, já era uma das maiores produtoras de torno do mundo, exportando para países ricos. A Weg, nos anos 1970, com menos de dez anos fundação, já havia iniciado o atendimento ao mercado externo. Assim, o resultado do processo de industrialização por substituição de importações foi muito complexo, gerando uma estrutura industrial heterogênea, em que empresas com estrutura avançada conviviam ao lado da produção tradicional.

Nos anos 1990 e 2000 as empresas efetivaram o processo de internacionalização instalando filiais e fábricas no exterior. Em 2012, a Weg Equipamentos foi a empresa líder do setor de bens de capital do Brasil, com vendas em torno de 4000 milhões de reais, sendo $43.5 \%$ das vendas para o mercado externo, apresentando-se entre as 200 maiores empresas em valor de mercado e maiores grupos da América Latina em termos de receita líquida. A Romi, no mesmo ano, apresentou faturamento de quase 500 milhões de reais, sendo 8\% destinados para o mercado externo (Revista Exame, 2013). 
ANEXO

\section{TABELA 1. ROMI: INVESTIMENTOS EM CONTROLADAS E COLIGADAS NO EXTERIOR EM 2012}

\begin{tabular}{|c|c|c|}
\hline Controlada & País & Objetivo principal \\
\hline $\begin{array}{l}\text { Romi Machine } \\
\text { Tools, Ltda. }\end{array}$ & $\begin{array}{l}\text { Estados } \\
\text { Unidos }\end{array}$ & $\begin{array}{l}\text { Distribuição de máquinas-ferramenta e fundi- } \\
\text { dos e usinados para a América do Norte. }\end{array}$ \\
\hline Romi A. L. S. A. & Uruguai & $\begin{array}{l}\text { Representação comercial para a América } \\
\text { Latina. }\end{array}$ \\
\hline $\begin{array}{l}\text { Romi Europa } \\
\text { GmbH }\end{array}$ & Alemanha & $\begin{array}{l}\text { Assistência técnica e apoio e revendedores da } \\
\text { Europa, Ásia, África e Oceania. }\end{array}$ \\
\hline $\begin{array}{l}\text { Burkhardt }+ \text { We- } \\
\text { ber Fertigungs- } \\
\text { systeme GmbH } \\
(\mathrm{B}+\mathrm{W})\end{array}$ & Alemanha & $\begin{array}{l}\text { Produção e comercialização de centros de } \\
\text { usinagem de grande porte, e de alta tecno- } \\
\text { logia, precisão e produtividade, assim como } \\
\text { máquinas para aplicações especiais. }\end{array}$ \\
\hline $\begin{array}{l}\text { Riello Sistemi } \\
\text { (Riello Shangai) } \\
\text { Trade }\end{array}$ & China & $\begin{array}{l}\text { Agente para comercialização, e serviços pós } \\
\text { venda, e de assistência técnica direta nas } \\
\text { máquinas-ferramenta produzidas pela } \mathrm{B}+\mathrm{W} \text {. }\end{array}$ \\
\hline $\begin{array}{l}\text { Burkhardt }+ \text { Weber } \\
\text { / Romi (Shangai) } \\
\text { Co., Ltd. }\end{array}$ & China & $\begin{array}{l}\text { Agente para comercialização, e serviços pós } \\
\text { venda, e de assistência técnica direta nas } \\
\text { máquinas-ferramenta produzidas pela } \mathrm{B}+\mathrm{W} \text {. }\end{array}$ \\
\hline $\begin{array}{l}\text { Sandretto Mexico } \\
\text { S. de R. L. de } \\
\text { C. V. }\end{array}$ & México & $\begin{array}{l}\text { Comercialização de máquinas, máquinas- } \\
\text { ferramenta, máquinas para plástico e fundi- } \\
\text { dos e usinados naquele mercado. }\end{array}$ \\
\hline Romi Itália S. R. L. & Itália & $\begin{array}{l}\text { Desenvolvimento de projetos, produção e } \\
\text { venda, distribuição, importação e expor- } \\
\text { tação de máquinas e equipamentos para o } \\
\text { processamento de matérias-primas plásticas } \\
\text { e distribuição de máquinas-ferramenta. }\end{array}$ \\
\hline $\begin{array}{l}\text { Controladas da } \\
\text { Romi Itália }\end{array}$ & & $\begin{array}{l}\text { Distribuição de máquinas para plásticos, } \\
\text { peças de reposição e assistência técnica. }\end{array}$ \\
\hline Sandretto UK Ltd. & Reino Unido & Sem descrição \\
\hline $\begin{array}{l}\text { Sandretto Indus- } \\
\text { tries S. A. S. }\end{array}$ & França & Sem descrição \\
\hline $\begin{array}{l}\text { Metalmecanica } \\
\text { Plast B. V. }\end{array}$ & Holanda & Sem descrição \\
\hline $\begin{array}{l}\text { Italprensas San- } \\
\text { dretto S. A. }\end{array}$ & Espanha & Sem descrição \\
\hline
\end{tabular}




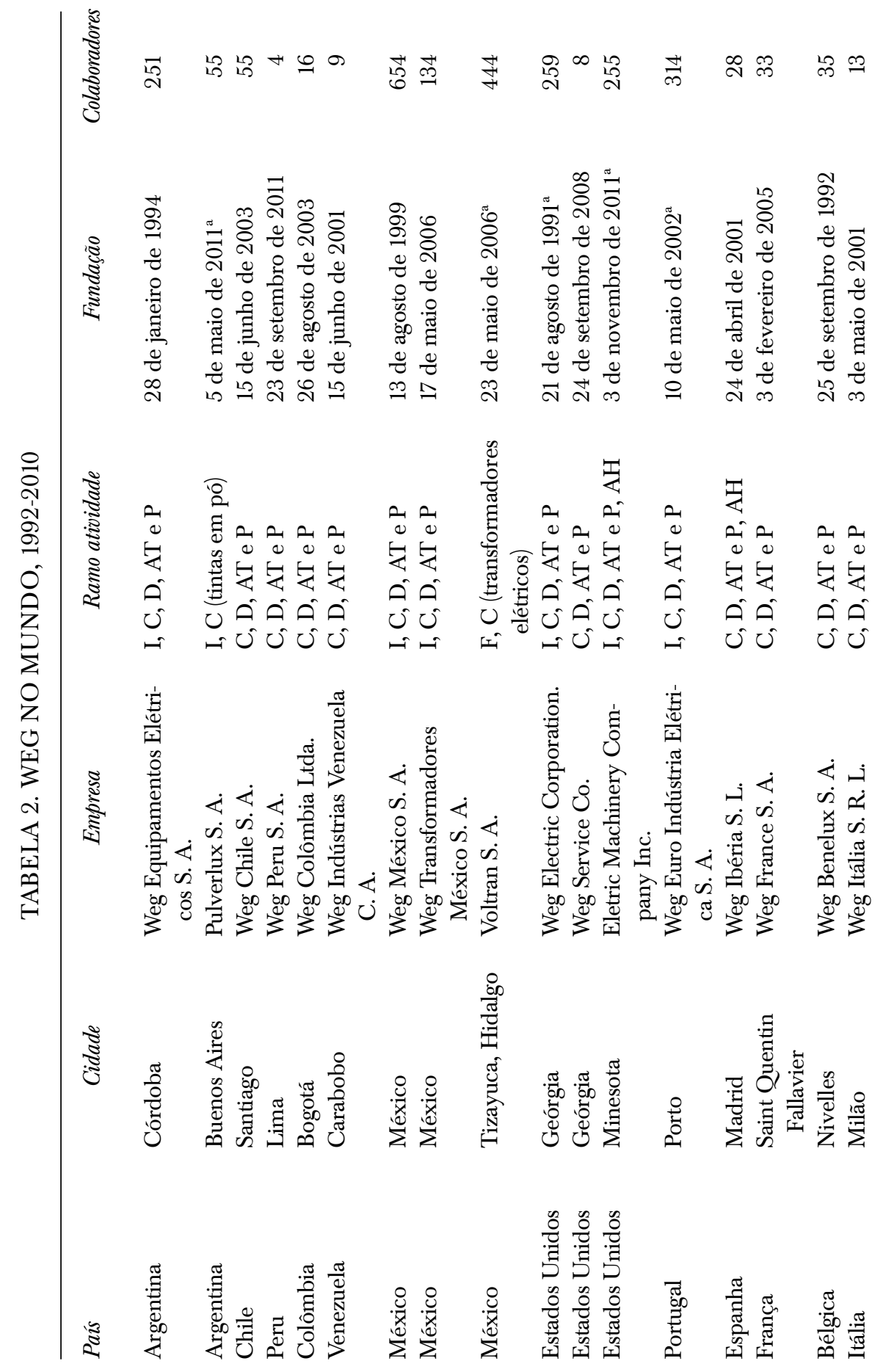




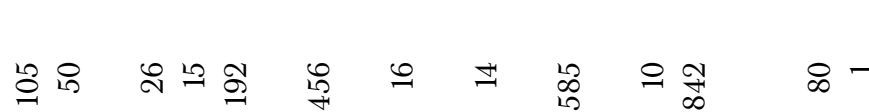

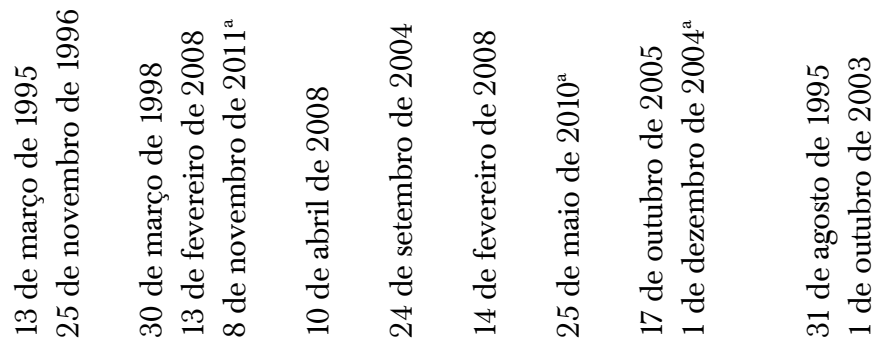

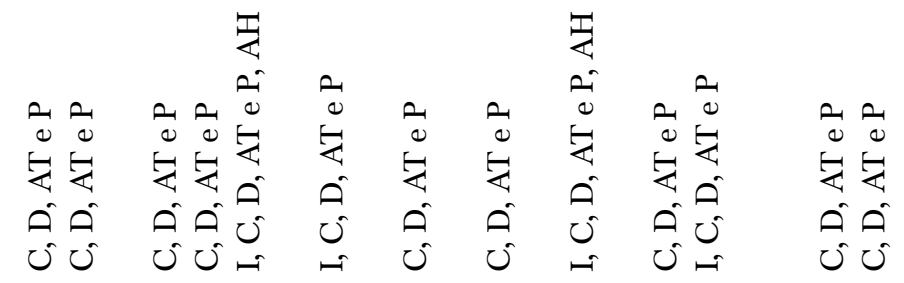

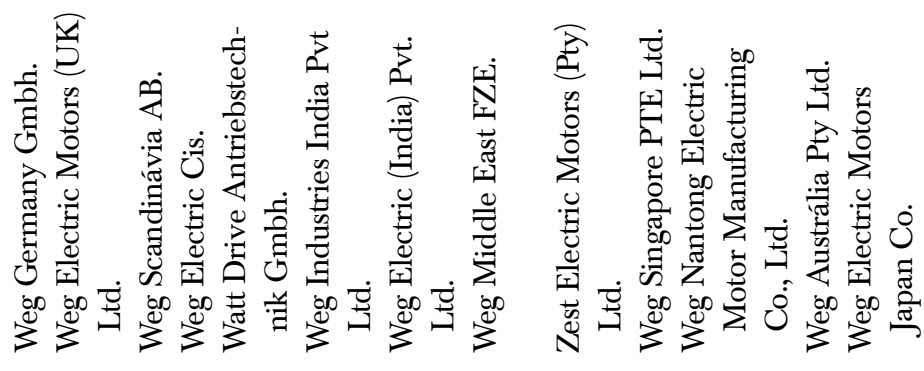

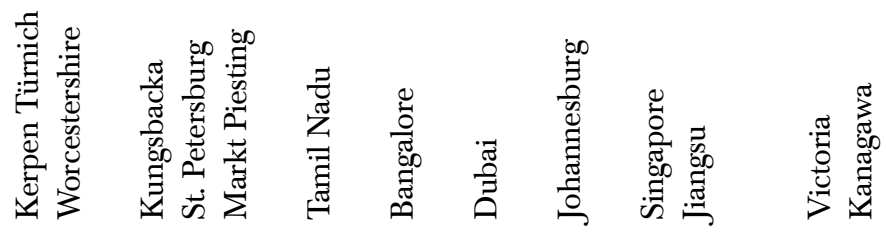

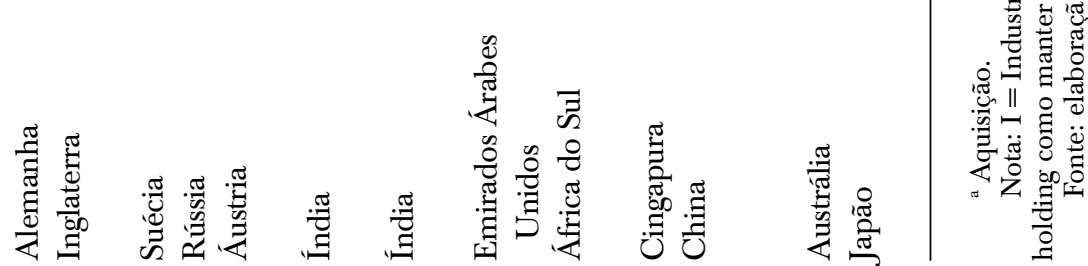




\section{REFERÊNCIAS}

Banas, G. (13 de abril, 1970). Quatro mosqueteiros de Santa Bárbara d'Oeste. Banas: Semanário Industrial e Financeiro, pp. 7-12.

Barbosa, A. (2006). Empresariado fabril e desenvolvimento econômico: empreendedores, ideologia e capital na indústria do calçado (Franca, 1920-1990). São Paulo: Editora Hucitec/Fundação de Amparo à Pesquisa do Estado de São Paulo.

BRANDÃO, M. A. (2009). Uma contribuição ao debate sobre a formação do empresariado industrial no Brasil: de lavoratori na Itália a patrone em Ribeirão Preto (1890-1930) (Tese de doutorado). Universidade Estadual Paulista, São Paulo, Brasil.

Bresser, L. C. (2002). Empresários, suas origens e as interpretações no Brasil. Em T. SzMrecsánYi e R. MARANHão (orgs.), História de empresas e desenvolvimento econômico. São Paulo: Hucitec/Associação Brasileira de Pesquisadores em História Econômica/Universidade de São Paulo.

Campos, M. A. (17 de setembro, 2013). Slides da palestra institucional: Seminário de Internacionalização para Colômbia. Weg. Recuperado de http://arq.apexbrasil. com.br/legado/eventos/2013/seminario-colombia/3_Apresentacao-WEG.pdf

Cano, W. (1975). Raizes da concentração industrial em São Paulo (Tese de doutorado). Universidade Estadual de Campinas, São Paulo, Brasil.

Comissão Econômica para A América latina e o CARibe [CePAl] (2000). Transformação produtiva com equidade: a tarefa prioritária do desenvolvimento da América Latina e do Caribe. Em R. Bielschowsky, Cinquenta anos de pensamento da CEPAL. Rio de Janeiro: Record.

Chandler, A. D. (1977). The visible hand: The managerial revolution in American Business. Cambridge: Harvard University Press.

Chataque, J. De M. (2004). A trajetória de crescimento da Weg: a folga de recursos humanos como propulsora do crescimento da firma (Dissertação de mestrado). Instituto de PósGraduação em Administração, COPPEAD, Rio de Janeiro, Brasil.

Chudnovsky, D. e LóPEz, A. (outubro-dezembro, 1999). As multinacionais latino-americanas: evolução e perspectivas de empresas da Argentina, Brasil, Chile e México. Revista Brasileira de Comércio Exterior.

Cyrino, Á. B. e Barcellos, E. P. (2006). Estratégias de internacionalização: evidências e reflexões sobre as empresas brasileiras. Em B. TANuRE e R. DuARTE, Gestão internacional. São Paulo: Saraiva.

Cyrino, Á. B. e Oliveira, M. de M. (2003). Emerging global players: Evidences from the internationalization processes of Brazilian firms. São Paulo: Associação Nacional de Pós-Graduação e Pesquisa em Administração.

DeAn, W. (1976). A industrialização de São Paulo (1880-1945). São Paulo: Difel.

DeAn, W. (1983). As multinacionais: do mercantilismo ao capital internacional. São Paulo: Brasiliense.

Diário de São Paulo (19 de fevereiro, 1939). Máquinas agrícolas Romi Limitada. Jornal Diário de São Paulo. 
Dunning, J. H. (1983). Changes in the level and structure of international production: the last one hundred years. Em M. CASsON (ed.), The Growth of International Business. Londres: George Allen \& Unwin.

FAJNZYlber, F. (2000). Industrialização na América Latina: da "caixa preta" ao "conjunto vazio". Em R. BielsChOWsKy, Cinquenta anos de pensamento da CEPAL. Rio de Janeiro: Record.

FISHLOW, A. (2013). Origens e consequências da substituição de importações: 40 anos depois. Em E. BACHA e M. B. DE Bolle, O futuro da indústria no Brasil: desindustrialização em debate. Rio de Janeiro: Civilização Brasileira.

Floriani, D. E., Borini, F. M. e Fleury, M. T. L. (outubro-dezembro, 2009). O processo de internacionalização como elemento gerador de capacidades dinâmicas: o caso da Web na Argentina e na China. Revista Brasileira de Gestão de Negócios, 11(33), 367-382.

Frieden, J. A. (2008). Capitalismo global: história econômica e política do século XX. Rio de Janeiro: Jorge Zahar Ed.

Haber, S. (2008). The political economy of industrialization. Em V. Bulmer-Thomas, J. H. Coatsworth e R. C. Conde, The Cambridge Economic History of Latin America (vol. II). Nova Iorque: Cambridge University Press.

Jones, G. (1996). The evolution of International Businnes. Londres: Routledge.

Jornal do Brasil (12 de fevereiro, 1979). Brasil é o $10^{\circ}$. Consumidor de máquinas-ferramenta. p. 15.

Lessa, C. (1998). A estratégia de desenvolvimento, 1974-1976 (2a. ed.) São Paulo: Universidade Estadual de Campinas.

Marson, M. D. (2012). Origens e evolução da indústria de máquinas e equipamentos em São Paulo, 1870-1960 (Tese de doutorado). São Paulo, Universidade de São Paulo. Recuperado de http://www.teses.usp.br/teses/disponiveis/12/12140/tde-19062012-185159 /pt-br.php

Melo, G. T. DE (2010). A reconfiguração dos recursos ao longo do processo de internacionalização de empresas: um estudo de caso na Weg $S$. A. (Dissertação de mestrado). Porto Alegre, Universidade Federal do Rio Grande do Sul.

Melo, G. T. DE (2013). Como, por que e para onde vamos? O caso de internacionalização da Weg. XXXVII em ANPAD. Rio de Janeiro, de 7 a 11 de setembro de 2013.

Mello, A. C. A., Caputo, A. C. e Marques, P. H. M. (dezembro, 2012). Motivação e impactos da internacionalização de empresas: um estudo de múltiplos casos na indústria brasileira. Revista do Banco Nacional do Desenvolvimento, 38, 139-180.

O Bandeirante (20 de maio, 1934). Pela indústria barbarense. Em Centro de Memória Romi.

Predebon, E. A. (2010). Internacionalização e integração econômica. O caso da Weg S. A. (Tese de doutorado). Universidade Federal do Paraná, Curitiba, Brasil.

Revista Exame (abril-julho, 1973). Os pioneiros: Emílio Romi: o construtor de máquinas.

Revista Exame (julho, 2013). Maiores e melhores. Edição especial: as 1000 maiores empresas do Brasil. 
Romi (1970a). Arquivos Romi. Catálogo IMOR, Máquinas Agrícolas Romi Ltda., Santa Bárbara do Oeste/São Paulo: Roman Ltda.

Romi (1970b). Arquivos Romi. Recorte “A fábrica da família Romi”, Santa Bárbara do Oeste, São Paulo.

Romi (2012). Relatório Anual. Romi: inovação constante para vencer desafios. Santa Barbara do Oeste-SP: Romi.

Romi (2014). Linha do tempo. Recuperado de http://www.romi.com.br/fileadmin/Editores/Empresa/4_Imagens_2014/Linha_do_tempo_2014.pdf

SANTA BÁrbara (24 de dezembro, 1933). Jornal Cidade de Santa Bárbara (Officinas Romi, Centro de Memória Romi).

SANTA BÁrbara (13 de maio, 1937). A riqueza intangível de S. Bárbara e o dinamismo criador de seu povo. Jornal Cidade de Santa Bárbara (Officinas Romi, Centro de Memória Romi).

SAntiso, J. (agosto, 2008). The emergence of Latin Multinationals. CEPAL Review, 95.

Schiavini, J. M., Scherer, F. L. e Moura, G. L. DE (outubro, 2011). O processo de internacionalização e expatriação: o caso da Weg S.A. na China. XIV SemeAd, Seminários em Administração.

SILVA, J. P. DA (2011). Processo de internacionalização da Weg. Palestra institucional do Gerente de Marketing Internacional e Vendas de Projetos Globais. Jaraguá do Sul.

Silva, S. (1976). Expansão cafeeira e origem da indústria no Brasil. São Paulo: Alfa Omega. VALDAliso, J. M. e LóPez, S. (2007). Historia económica de la empresa. Barcelona: Crítica.

VeigA, L. F. A. DA e RochA, A. DA (2003). Expansão internacional de grandes empresas: estabelecendo relacionamentos no mercado internacional. Em A. DA RoCHA, As novas fronteiras: a multinacionalização das empresas brasileiras. Rio de Janeiro: Mauad.

Visão, Revista Semanal (11 de agosto, 1961). Torno vai, divisa vem.

WEG (2001). Livro de comemoração aos 40 anos da Weg. Jaraguá do Sul- SC: Weg.

WEG (31 de dezembro, 2013). Relatório Anual Integrado. Jaraguá do Sul- SC: Weg. 